\title{
Road transport vibration stress impact on 'Palmer' mangoes quality and shelflife
}

\author{
Josenara Daiane de Souza Costa ${ }^{1}$, Acácio Figueiredo $\mathrm{Neto}^{2}$, Nelson Cárdenas Olivier ${ }^{3}$, \\ Marcos Antônio da Silva Irmão ${ }^{4}$, Marylia de Sousa Costa $^{5}$, Josivanda Palmeira Gomes ${ }^{6}$
}

\begin{abstract}
Studying the causes of postharvest fruit loss is important to avoid reduction of quality and quantity for the consumer due, for example, to the influence of frequent impacts from vibrations during transportation. In this sense, this study evaluates the storage quality of 'Palmer' mangoes after being subjected to different simulated road transport vibrations. Vibration was simulated from the analysis of the profile of the frequencies generated in road transport of fruit, determined in a tractor trailer. 'Palmer' mangoes stored after vibration stress were evaluated for: mass loss, absorbance difference index (IAD), peel and pulp browning index (BI), pulp firmness, soluble solids content, and titratable acidity. The development of a vibration machine made it possible to satisfactorily simulate specific vibration frequencies. Vibration stress during simulated transport led to accelerated weight loss, decreased pulp firmness, and peel browning in 'Palmer' mangoes. Index terms: Simulated transport, postharvest losses, fruit, mechanical damage, browning index.
\end{abstract}

\section{Impacto de estresse de vibração de transporte rodoviário na qualidade e vida útil de mangas 'Palmer'}

\author{
Corresponding author: \\ acacio.figueiredo@univasf.edu.br \\ Received: April 16, 2020 \\ Accepted: January 18, 2021 \\ Copyright: All the contents of this \\ journal, except where otherwise \\ noted, is licensed under a Creative \\ Commons Attribution License.
}

\begin{abstract}
Resumo - O estudo das causas de perdas na pós-colheita de frutas é importante para evitar a redução da qualidade e do quantitativo destinado ao consumidor, decorrentes, por exemplo, da influência de impactos frequentes devido às vibrações durante o transporte. Neste sentido, objetivou-se com este estudo avaliar a qualidade de mangas 'Palmer' no armazenamento, após serem submetidas a diferentes esforços simulados de impacto decorrente do transporte rodoviário. A partir da análise do perfil das frequências geradas no transporte rodoviário de frutas, determinado na parte traseira de um caminhão, houve a simulação da vibração e a avaliação da qualidade de mangas 'Palmer' armazenadas após o estresse vibratório, em relação à: perda de massa, índice de diferença de absorbância (índice DA), índice de escurecimento (IE) da casca e da polpa, firmeza da polpa, teor de sólidos solúveis e acidez titulável. Ao final do desenvolvimento da máquina, foi capaz de simular frequências específicas de vibração de forma satisfatória. $\mathrm{O}$ estresse por impacto durante o transporte simulado acelerou a perda de massa, a diminuição da firmeza da polpa e o escurecimento da casca de mangas 'Palmer'.
\end{abstract}

Termos para indexação: Transporte simulado, perdas pós-colheita, fruto, danos mecânicos, índice de escurecimento.

${ }^{1}$ D.Sc., Professor at Instituto Federal de Educação, Ciência e Tecnologia do Piauí, Valença do Piauí-PI, Brazil. E-mail: josenara.costa@ifpi.edu.br (oRcid: 0000-0002-8706-7405)

${ }^{2}$ D.Sc., Professor at College Academic of Environmental an Agricultural Engineering, Universidade Federal do Vale do São Francisco, JuazeiroBA, Brazil. E-mail: acacio.figueiredo@univasf.edu.br (ORCID: 0000-0002-0326-9123)

${ }^{3}$ D.Sc., Professor at College Academic of Mechanical Engineering, Universidade Federal do Vale do São Francisco, Juazeiro-BA, Brazil. E-mail: nelson.cardenas@univasf.edu.br (ORCID: 0000-0003-0501-4949)

${ }^{4}$ D.Sc., Professor at College Academic of Mechanical Engineering, Universidade Federal do Vale do São Francisco, Juazeiro-BA, Brazil. E-mail: marcosunivasf2015@gmail.com ${ }^{\text {(ORCID: 0000-0002-7760-991X) }}$

${ }^{5}$ M.Sc., PhD student at Department of Agricultural Engineering, Universidade Federal de Campina Grande, Campina Grande-PB, Brazil. E-mail: marylia.sousacosta@gmail.com ${ }^{\text {(ORCID: 0000-0001-9593-4233) }}$

${ }^{6}$ D.Sc., Professor at Department of Agricultural Engineering, Universidade Federal de Campina Grande, Campina Grande-PB, Brazil. E-mail: josivanda@gmail.com ${ }^{\text {(ORCID: } 0000-0002-2047-986 \mathrm{X})}$ 


\section{Introduction}

Mango is one of the most produced fruits in the world, accounting for more than half of total tropical fruit production in 2017. That same year, Brazil reached the third place among exporting countries, mainly due to its capacity to produce mangoes perennially (ALTENDORF, 2019), the fruit being mainly exported in natura.

Transport is a crucial component in the distribution of fresh food products from harvest to consumer (SPRINGAEL et al., 2018). In general, agricultural products are more difficult to manage properly than industrial commodities in terms of logistics because they are highly sensitive to vibration stress during transportation (JUNG et al., 2018).

Vibration generated by vehicles during road transport is one of the causes of fruit damage, which can be visually detectable or not. Qualitative and quantitative changes caused by vibration in fruits have been studied by several researchers in recent years, for fruits such as: watermelon (SHAHBAZI et al., 2010), melon (ZHOU et al., 2015), banana (WASALA et al., 2015), grape (JUNG et al., 2018), apple (SPRINGAEL et al., 2018), and kiwifruit (TABATABAEKOLOOR et al., 2013; WEI et al., 2019).

Springael et al. (2018) stressed that transport vibrations are a major contributor to apple perforations and, as a result, losses can be attributed to fungal diseases that enter through injured or perforated tissues and contaminate the fruit. In this case, the authors suggest a cost-based transport route planning, avoiding road segments that are poorly maintained or more susceptible to induce higher vibration amplitudes, for thus decreasing the loss rate of apples.

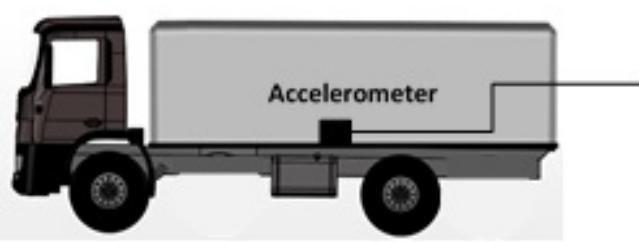

Figure 1. Vibration data acquisition system diagram.

An unloaded tractor trailer was prepared to receive a vibration sensor (accelerometer) in the center of the trailer floor. The accelerometer was attached to the floor by a wax used especially for this procedure, and was connected by shielded cables to the frequency analyzer (data acquisition), which in turn communicates to the laptop (processing and analysis), from where the collected data can be viewed and stored.
Jung et al. (2018) and Wei et al. (2019) simulated laboratory-scale vibration experiments to evaluate the effect of transport stress on fruit quality. The first authors verified that vibration stress resulted in greater weight loss and higher ethylene production, which could accelerate the degradation of packed grapes. Similarly, Wei et al. (2019) concluded that the simulated transport vibration caused intracellular damage to kiwifruit tissues, accelerating water loss and wilting.

Since vibrations directly influence product quality and integrity, it is essential to gain insight into the magnitude that occurs during transportation. This way, researchers may use information to perform advanced simulation testing, aggregating information for packaging designs (PATERNOSTER et al., 2018) and production outlets.

Therefore, this study evaluates the storage quality of 'Palmer' mangoes after being subjected to simulated road transport vibration stress.

\section{Materials and methods}

\section{Analysis of the frequencies generated in road transport of fruit}

To determine vibration conditions that most resemble those of the road transport of mangoes intended for export, we carried out a test with a truck (tractor-trailer combination) at an average speed of $75 \mathrm{~km} / \mathrm{h}$. The truck traveled a distance of $210 \mathrm{~km}$ in a paved road along the BR-407 highway, which connects the cities of Petrolina, in Pernambuco State, and Jaguarari, in Bahia State.

The assembled system for the acquisition of vibration data consisted of a two-axle tractor trailer; a Dytran accelerometer $(2-10000 \mathrm{~Hz})$, a frequency spectrum analyzer, a laptop, and the Rt Pro Photon software for data processing (Figure 1).
The parameter used to calculate the signal energy in each frequency band was the root mean square (RMS) or quadratic mean (Equation 1), with results expressed as $g\left(9.81 \mathrm{~m} / \mathrm{s}^{2}\right)$. 
Where $\mathrm{f}(\mathrm{t})$ is the temporal function of vibrations in each frequency band.

A wide frequency range of up to $1 \mathrm{kHz}$ has been selected. The signals obtained during the ride correspond to 4096 point signals lasting $1.6 \mathrm{~s}$. Once the signals were obtained, they were processed for a better identification of their frequency content. Frequency band analysis was then performed to classify bands with higher vibration energy during the ride. Initially, $100-\mathrm{Hz}$-wide frequency bands were used for the entire frequency domain $(0-1$ $\mathrm{kHz}$ ). Subsequently, the $0-100 \mathrm{~Hz}$ band was selected, which was subdivided into $10-\mathrm{Hz}$ intervals.

$$
\mathrm{X}_{\mathrm{RMS}}=\sqrt{\frac{1}{\mathrm{~T}} \int_{0}^{\mathrm{T}} \mathrm{f}(\mathrm{t})^{2} \mathrm{dt}}
$$

\section{Vibration simulation machine}

Steel tubes (SAE - 1020 AND SAE-1045) were used to manufacture the machine. The steel structure had the following dimensions: $101 \mathrm{~cm}$ length, $60 \mathrm{~cm}$ width, and $27 \mathrm{~cm}$ height. Moreover, it comprised four springs (220 $\mathrm{mm}$ height, $36 \mathrm{~mm}$ internal diameter, $50.5 \mathrm{~mm}$ external diameter) at its ends to provide static and dynamic balance as well as impact cushioning to the machine. To verify the spring stiffness constant, a compression test was performed using a universal electromechanical testing machine (model EMIC DL 10,000) controlled by a microcomputer through the software TESC (version 3.04 ), using a $100-\mathrm{mm}$ diameter cylindrical plate at a compression speed of $1 \mathrm{~mm} / \mathrm{s}$.
To ensure the balance of the machine, average deformation in its median side portions was determined using two digital comparing clocks through a vibration test $(40 \mathrm{~Hz}$ ), with a total load of $258 \mathrm{~N}$ (simulated weight of six 4-kg export-type boxes with size 8 mangoes) and a fixed width of $1.2 \mathrm{~mm}$. This deformation was measured by the difference between spring length before and after five tests.

The 'came' mechanism was used to originate the vibration, consisting of a Scotch yoke, a bearing, and a shaft. Shaft rotation was originated by the torque of a 1-hp three-phase electric motor (model KJN 60M1-4) driven by a CFW-10 frequency inverter. Torque transmission from motor to shaft was given through the use of a V-belt and two pulleys, one being fitted to the motor shaft and the other to the concentric end of the shaft.

A wooden structure $(65 \mathrm{~cm} \times 110 \mathrm{~cm})$ was made to be placed on the metal structure to arrange the boxes containing the fruits. The entire assembly was fixed to a concrete platform (inertia bench, Figure 2) to minimize possible interference with the built mechanical system.

For the simulated vibration tests, the system used consisted of an accelerometer, a frequency spectrum analyzer, and a software (Figure 3), whose specifications are the same as those used in the tractor trailer vibration analysis.
A.

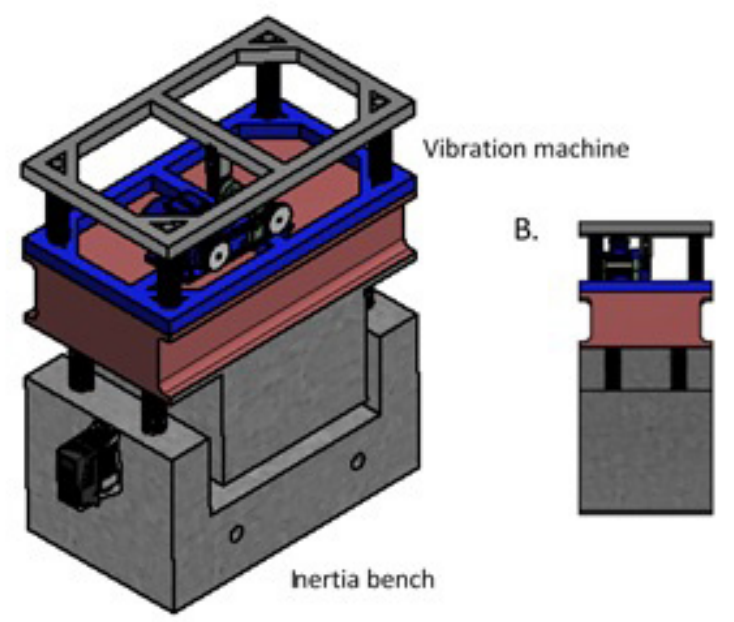

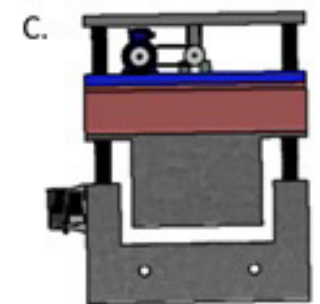

Figure 2. Schematic diagram with the general view (A), side view (B) and front view (C) of the vibrating machine. 


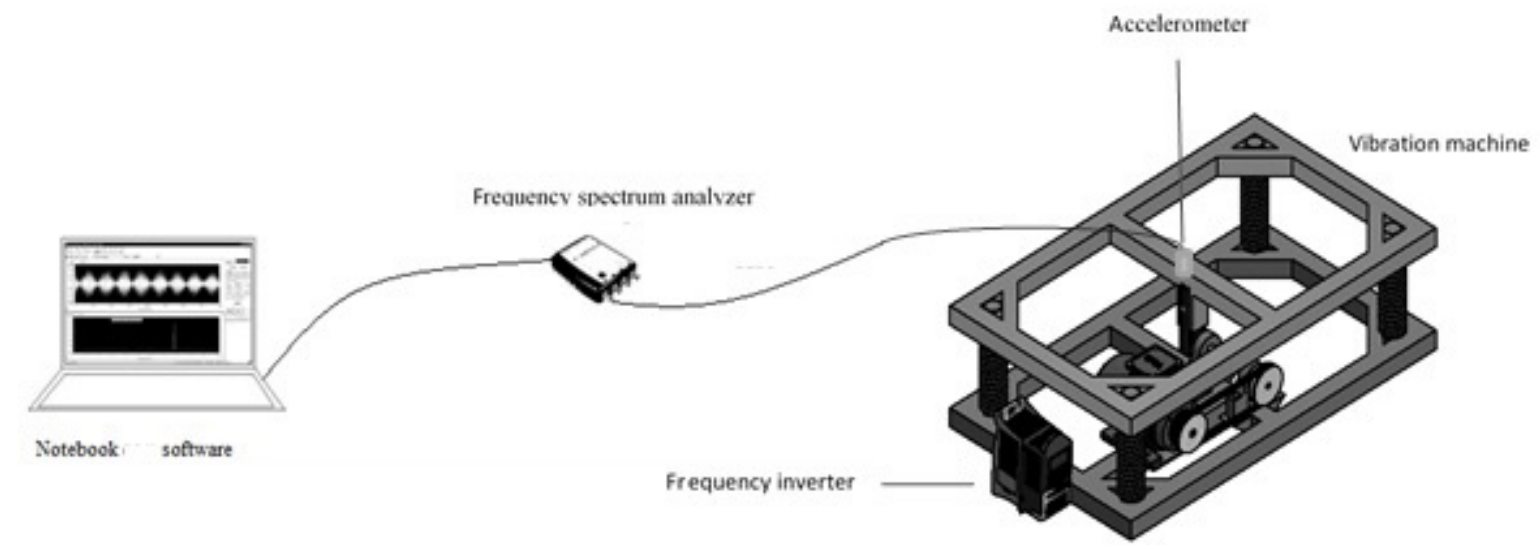

Figure 3. System for exploratory testing on the vibrating machine.

\section{Raw material acquisition}

Palmer mangoes were obtained from the Grand Valle Farm, located in Petrolina city, Pernambuco State. The fruits were size 8 and were at ripening stage 2 , external appearance of the fruit being $75 \%$ green and $25 \%$ purple (ASSIS, 2004). After processing in the packing house, the mangoes were transported to the laboratory for experiments, using a total of 192 fruits.

\section{Experimental conditions}

The tests were performed with three constant vibration frequencies determined after exploratory studies. These tests lasted $7 \mathrm{~h}$, simulating the time it takes from Petrolina city to the Port of Salvador, Bahia, at approximately $529 \mathrm{~km}$.

Six export-type cardboard boxes $(350 \mathrm{~mm} x$ $285 \mathrm{~mm} \times 105 \mathrm{~mm}$ ) were used for each test. The boxes were placed side by side, containing eight fruits each, simulating transport in a refrigerated room at $16{ }^{\circ} \mathrm{C}$ and $68 \pm 4 \%$ relative air humidity $(\mathrm{RH})$. After this stage, the fruits were stored in B.O.D. at $12 \pm 1{ }^{\circ} \mathrm{C}$ and $58 \pm 2 \% \mathrm{RH}$ for 28 days, being evaluated every seven days.

The experimental design was completely randomized with five replicates, each one consisting of a fruit, in a $4 \times 5$ factorial scheme representing four constant vibration frequencies $(0,20,30$, and $40 \mathrm{~Hz})$ and five storage periods $(0,7,14,21$, and 28 days). The results were submitted to analysis of variance by the Tukey test at $5 \%$ probability, and regression analysis was performed using the Assistat software (Version 7.7, beta) (SILVA; AZEVEDO, 2016).

\section{Evaluations during storage}

To evaluate possible damage caused by transport vibration, the fruits were evaluated during storage for weight loss, absorbance difference index (IAD), peel and pulp browning index (BI), pulp firmness, soluble solids content, and total titratable acidity according to the following methodologies:
Mass loss - determined with the aid of a semianalytical scale $(0.01 \mathrm{~g})$, with results expressed as a percentage (Equation 2).

$$
\text { Mass Loss }(\%)=\frac{I W-F W}{I W} \times 100
$$

Where:

IW = initial mass of the sample, in grams, over a given period;

$\mathrm{FW}=$ final mass of the sample, in grams, in the period following IW.

Pulp firmness - determined by penetration tests using a universal electromechanical testing machine (model EMIC DL 10,000) through the software TESC (version 3.04), adapted for experiments with agricultural products. After partial removal of the epidermis, the fruits were placed in rest position, being then subjected to a penetration of $1 \mathrm{~mm} / \mathrm{s}$ to a depth of $25 \mathrm{~mm}$, with a $6-\mathrm{mm}$ tip. Results were expressed in Newtons (N).

Peel and pulp browning index (BI) - peel and pulp color coordinates were obtained from the averages of two readings at equidistant points of each fruit using a portable digital colorimeter (brand Konica Minolta DP-400). These coordinates are: L, which corresponds to brightness (luminosity, clarity, or reflectance, where 0 represents dark/opaque, and 100 represents white); a* (in which negative values correspond to intensity of green color, and positive values correspond to intensity of red color); and $b^{*}$ (in which negative values correspond to intensity of blue color, and positive values correspond to intensity of yellow color). From the obtained values, peel and pulp browning indexes were determined (PATHARE et al., 2013; OLIVEIRA, 2013).

Soluble solids (SS) - determined by a digital refractometer (Invert Sugar Refractometer HI 96804) with automatic temperature compensation. Results were expressed as ${ }^{\circ}$ Brix. 
Titratable acidity (TA) - determined by titrating the sample with sodium hydroxide solution $(0.1 \mathrm{M} \mathrm{NaOH})$ using 1\% phenolphthalein as an indicator (IAL, 2008). Results were expressed as percent citric acid.

Except for mass loss, all evaluations were made on both sides of the fruits, considering the rest position.

\section{Results and discussion}

\section{Analysis of the frequencies generated in road transport of fruit}

The frequency spectrum obtained after the tractor trailer test was wide, up to $1 \mathrm{kHz}$, but the signal amplitude was greater for the range from 1 to $100 \mathrm{~Hz}$ (Figure 4). The results corroborate those of Jung et al. (2018), who also simulated road transport when studying grape distribution routes, obtaining a frequency range between 1 and $200 \mathrm{~Hz}$, with higher energy levels up to $100 \mathrm{~Hz}$. The authors found that the fruits under study were damaged due to the large vibration shift in low frequency bands $(<40 \mathrm{~Hz})$. These low frequencies can be attributed both to road roughness and to the truck's structure, including suspension system and tire types (PATERNOSTER et al., 2017).

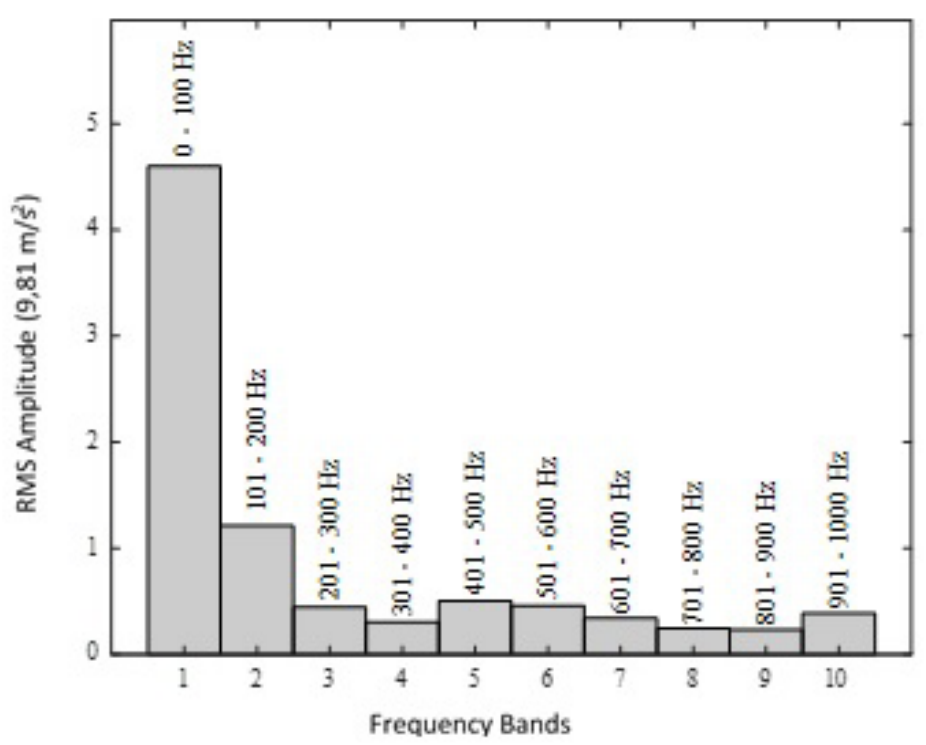

Figure 4. Amplitude analysis by frequency bands.

The most representative frequency band (0$100 \mathrm{~Hz}$ ) was subdivided (Figure 5), in which the lowest end $(0-10 \mathrm{~Hz})$ was subtracted because it represents energy levels for parked vehicles and low vibration amplitudes. From $40 \mathrm{~Hz}$ onwards a resonance effect was observed, a phenomenon that should be avoided in the design of structures and machines, since large vibration amplitudes can accelerate the failure process due to fatigue, discomfort, noise, among other problems (SILVA, 2009). The highest RMS values were found in the 11-20 $\mathrm{Hz}, 21-30 \mathrm{~Hz}$, and 31-40 Hz ranges. To simulate extreme conditions, the vibration table simulation tests used the highest vibration frequencies of these three intervals, considering that the frequency levels were the same across the truck floor and constant during transportation. 


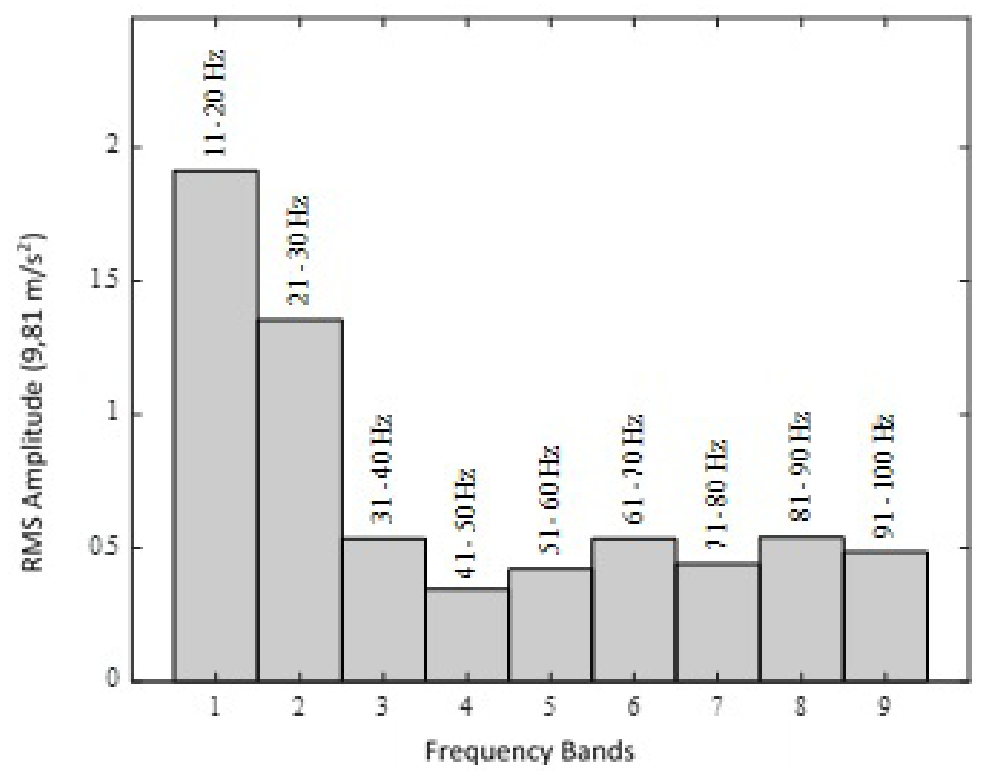

Figure 5. Amplitude analysis by frequency bands from 0 to $100 \mathrm{~Hz}$.

\section{Vibration simulation machine}

Spring compression tests showed a linear and homogeneous spring behavior (Figure 6), leading to a balanced system. This was confirmed in the exploratory test, where by applying a force of $258 \mathrm{~N}$, the comparing clocks pointed to an average deformation of approximately $10.56 \mathrm{~mm}$.
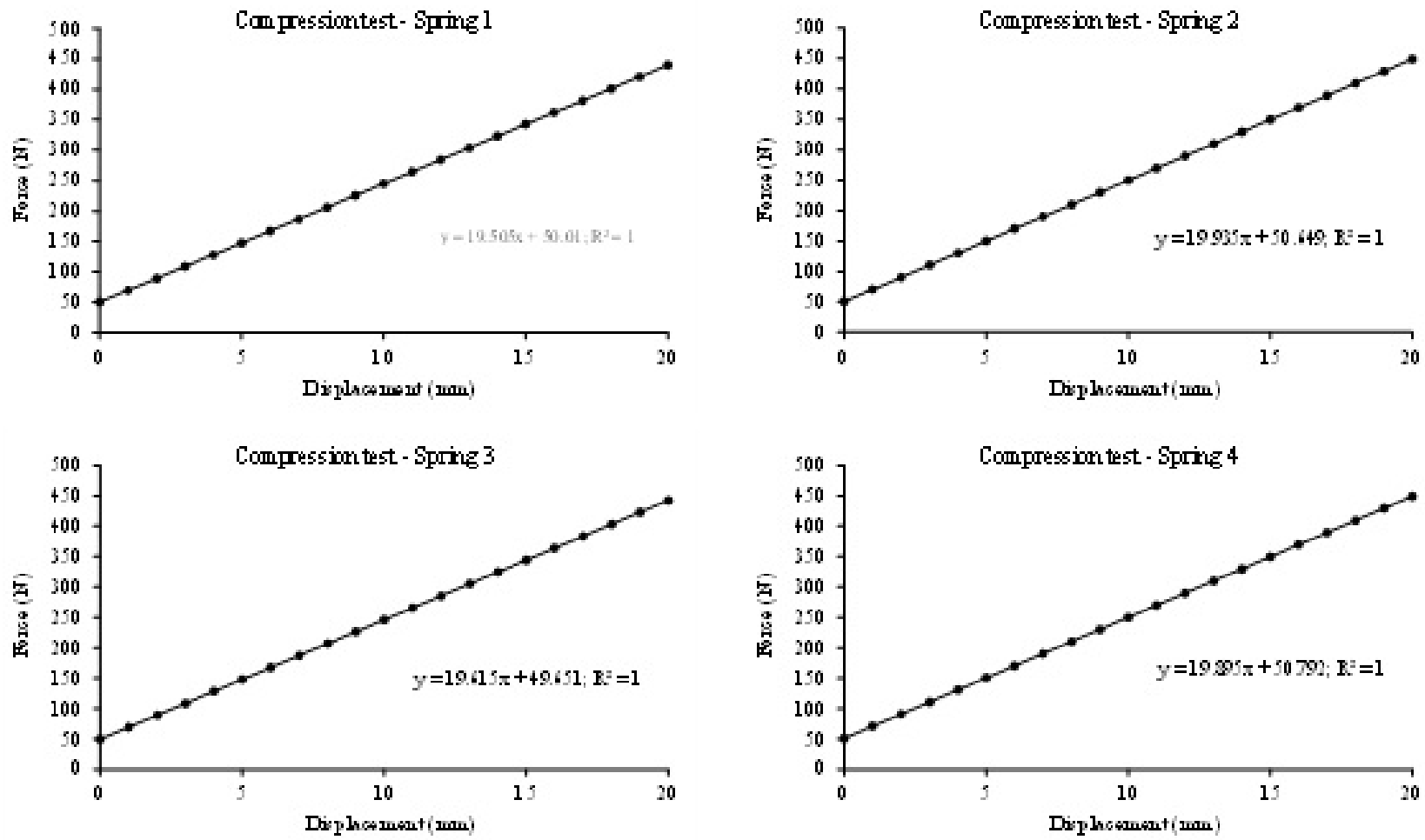

Figure 6. Deformation of the four springs used in the vibration machine during compression testing. 


\section{Evaluations during storage}

After 'Palmer' mangoes were subjected to vibration during storage, the movement of fruit water towards the environment was possibly intensified, resulting in an increase in weight loss proportional to the increase in vibrational frequency (Figure 7). Considering that the reduction in fruit weight is an important aspect for the market, the quality factor was affected. Mangoes under vibration stress of 20,30 , and $40 \mathrm{~Hz}$ lost around $9 \%, 10 \%$, and $12 \%$ of their weight, respectively, after twenty-eight days of refrigerated storage, while in the control group this loss was $7 \%$.

The increase in weight loss was gradual for all evaluated mangoes, similar to what was verified by Jung et al. (2018), where the reduction in grape weight after simulated transport increased with storage time. The authors found that fruits under stress lost $6 \%$ more weight than those in the control group, relating the acceleration of moisture content reduction to the increase in the amount of ethylene released by respiration intensification caused by grape stress during transportation. Wei et al. (2019) observed that although there was no visible damage to the surface of 'Xuxiang' kiwifruit, simulated vibration $(20 \mathrm{~Hz}$ for 5 hours) stimulated water loss, which was attributed to intracellular damage that accelerated fruit wilting. This loss may affect fruit firmness and ripening, reinforcing the importance of the type of packaging and transportation of fruits in ensuring good quality for end consumers.

Mango pulp firmness decreased with increasing storage time and vibration intensities. Pulp firmness decreased from $137 \mathrm{~N}$, at baseline, to approximately 43 $\mathrm{N}$ for the fruits that did not undergo vibration, and to 37 , 21 , and $13 \mathrm{~N}$ at the end of storage after vibration at a frequency of 20,30, and $40 \mathrm{~Hz}$, respectively (Figure 8).

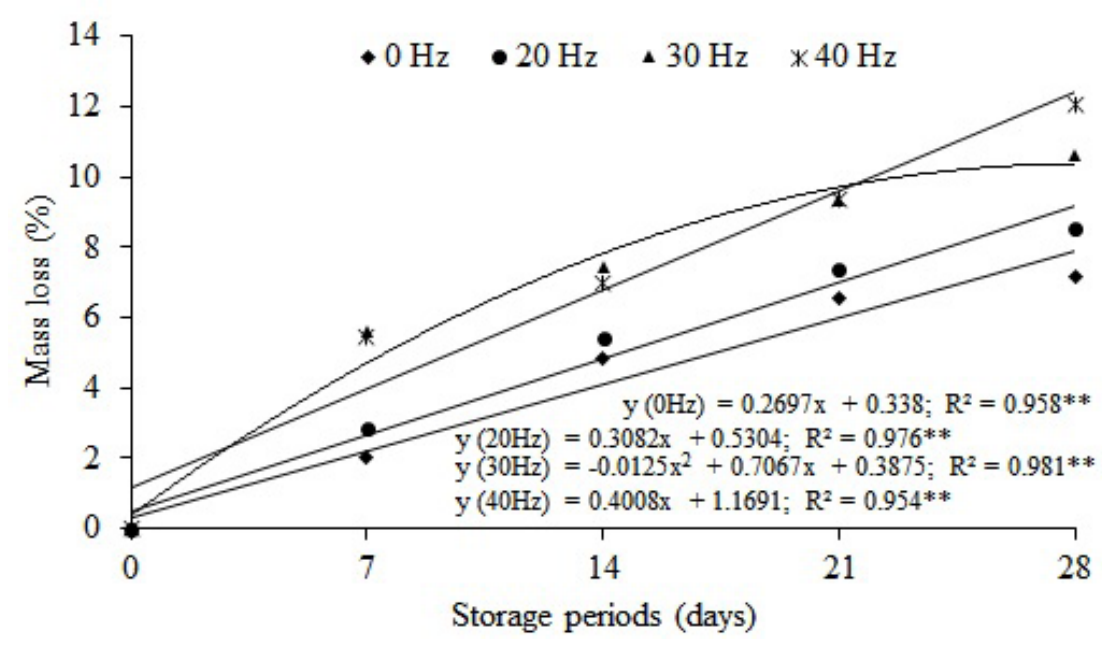

Figure 7. Mass loss of 'Palmer' mangoes stored under refrigeration for twenty-eight days and subjected to vibration at different frequencies.

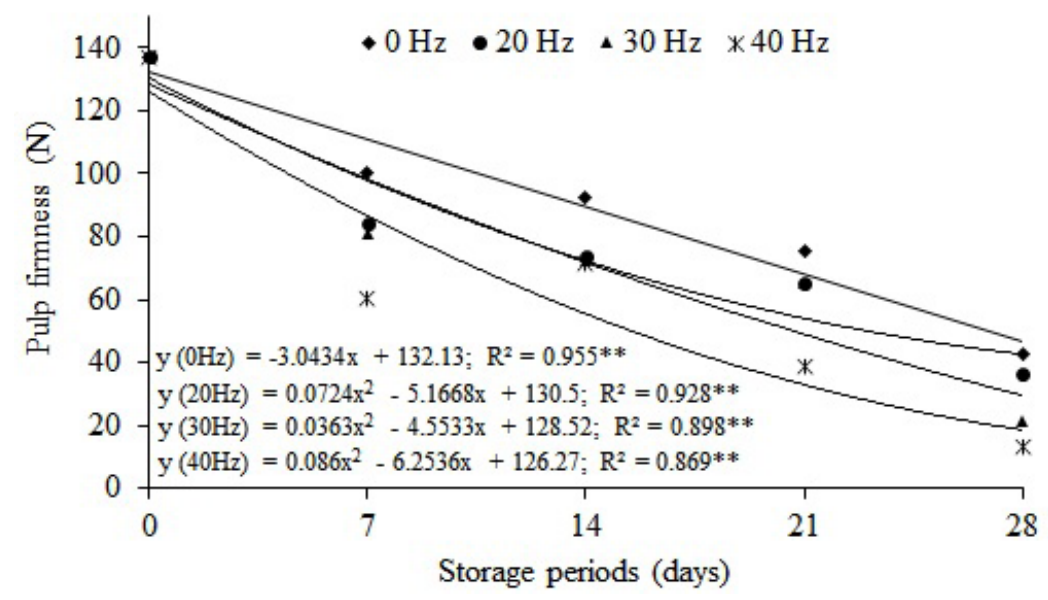

Figure 8. Pulp firmness of 'Palmer' mangoes stored under refrigeration for twenty-eight days and subjected to vibration at different frequencies. 
Minimizing vibration intensities during transportation can reduce firmness loss and, consequently, quality loss in 'Palmer' mangoes. These findings corroborate those of Zhou et al. (2015), in which short shelf life and rapid loss of quality of 'Hami' melons were attributed to transport vibration. The firmness of melons subjected to vibration in a $2-200 \mathrm{~Hz}$ spectral band was $52.9 \%$ lower than that of control fruits at twenty-eight days of storage, revealing that vibration increased melon softening due to cell membrane leakage, hydrolase activity, and loss of cell wall constituents.
Regarding color coordinates $\left(\mathrm{L}^{*}, \mathrm{a}^{*}, \mathrm{~b}^{*}\right)$, the peel browning index increased significantly with both storage time and vibration frequency variation (Figure 9A). Fruits that underwent vibration showed greater peel browning at the end of storage, which indicates a degradative effect that may influence the acceptance of the consumer market.
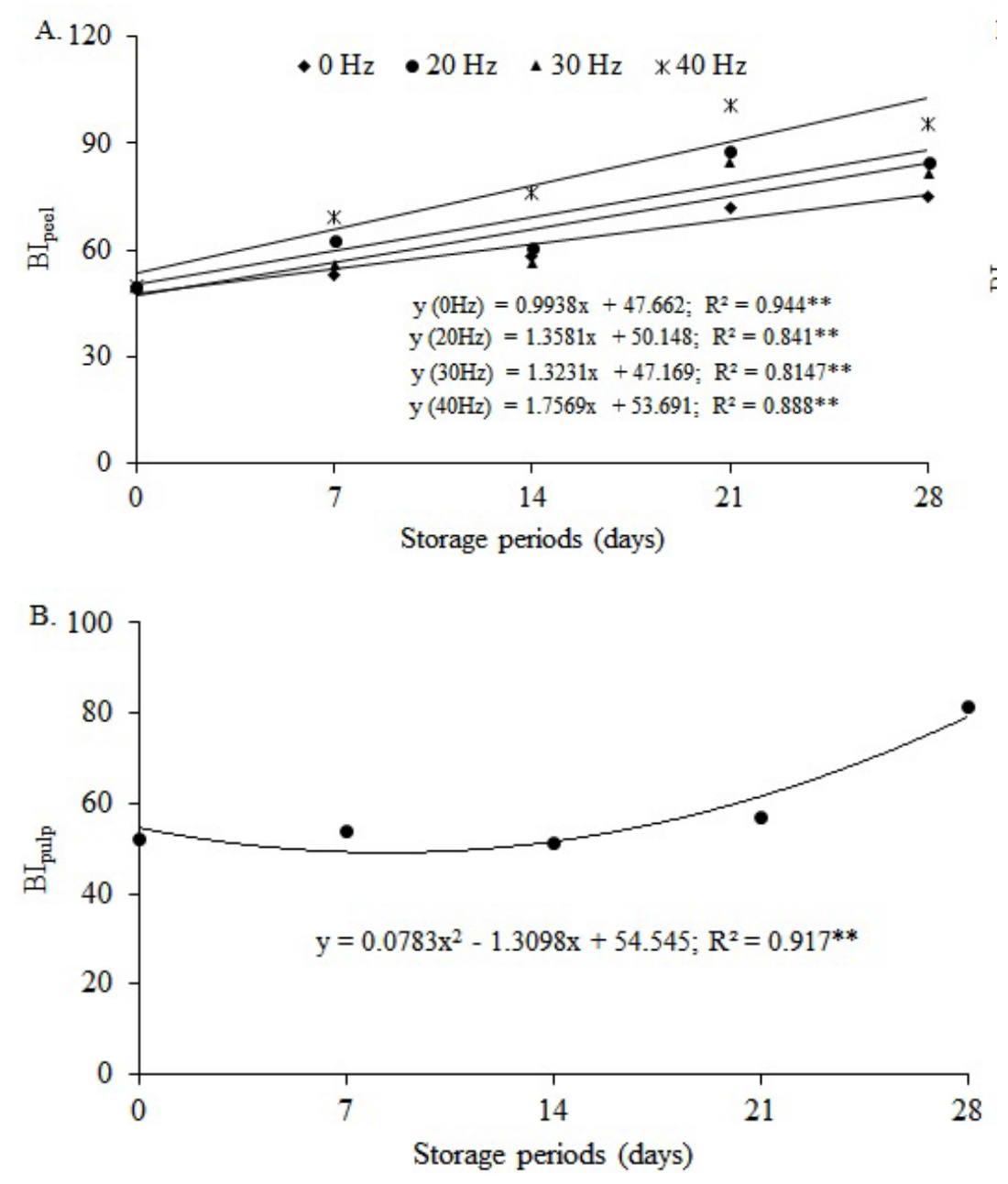

Figure 9. Peel browning index (A) and pulp browning index (B) of 'Palmer' mangoes stored under refrigeration for twenty-eight days and subjected to vibration at different frequencies.

Although no immediate damage was detected in the fruits, tissue degradations that require time for verification, such as spots resulting from vibration impacts, were observed (Figure 10). In general, the occurrence was progressive; however, not all fruits were affected by this damage. For fruits that underwent vibration at $20 \mathrm{~Hz}$, no visible damage was verified. However, at 30 and $40 \mathrm{~Hz}$, damage was verified from the seventh day of storage. This damage compromises the marketing of mangoes, given that international markets set as minimum quality standards for fresh mango fruits that, after packed, they must be intact, firm, fresh in appearance, free of foreign matter, without damage caused by pests or low temperatures, and without stains or mechanical damage (EMBRAPA, 2000). 

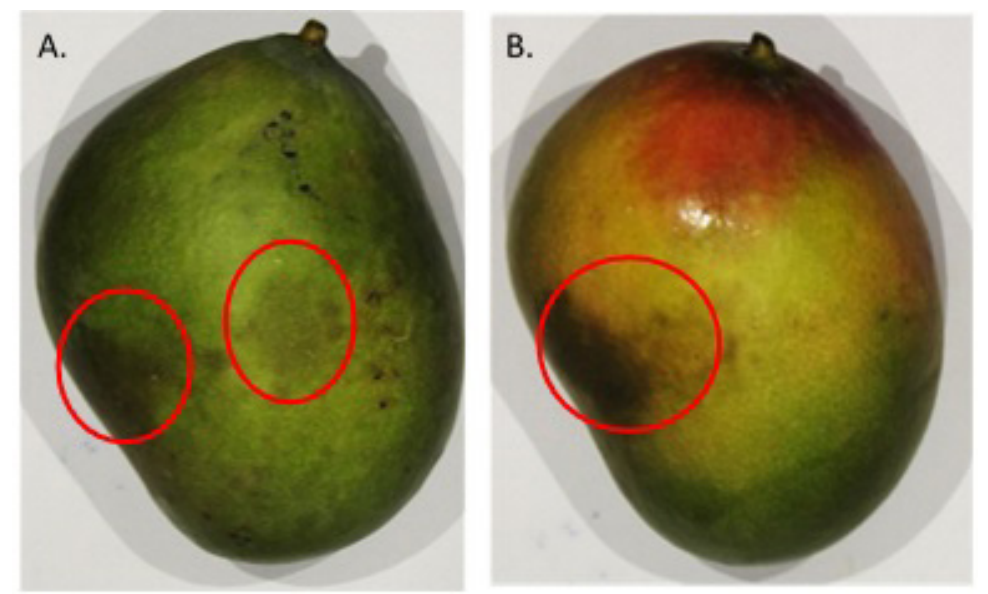

Figure 10. Damage to 'Palmer' mangoes after vibration with simulated transport at $40 \mathrm{~Hz}$, stored for seven (A) and twenty-eight days (B) under refrigeration.

Pulp browning was not affected by vibration, increasing as a function of storage time (Figure 9B). The same was observed by Miguel et al. (2013) in 'Palmer' mangoes kept at $12{ }^{\circ} \mathrm{C}$ for twenty-one days, and by Costa et al. (2017) when studying the shelf life of 'Tommy Atkins' mangoes. This increase in browning can be promoted by reduced light reflection due to lower pulp water content.
Neither soluble solids content nor titratable acidity were affected by vibration, contrary to what was observed for storage time (Figure 11).
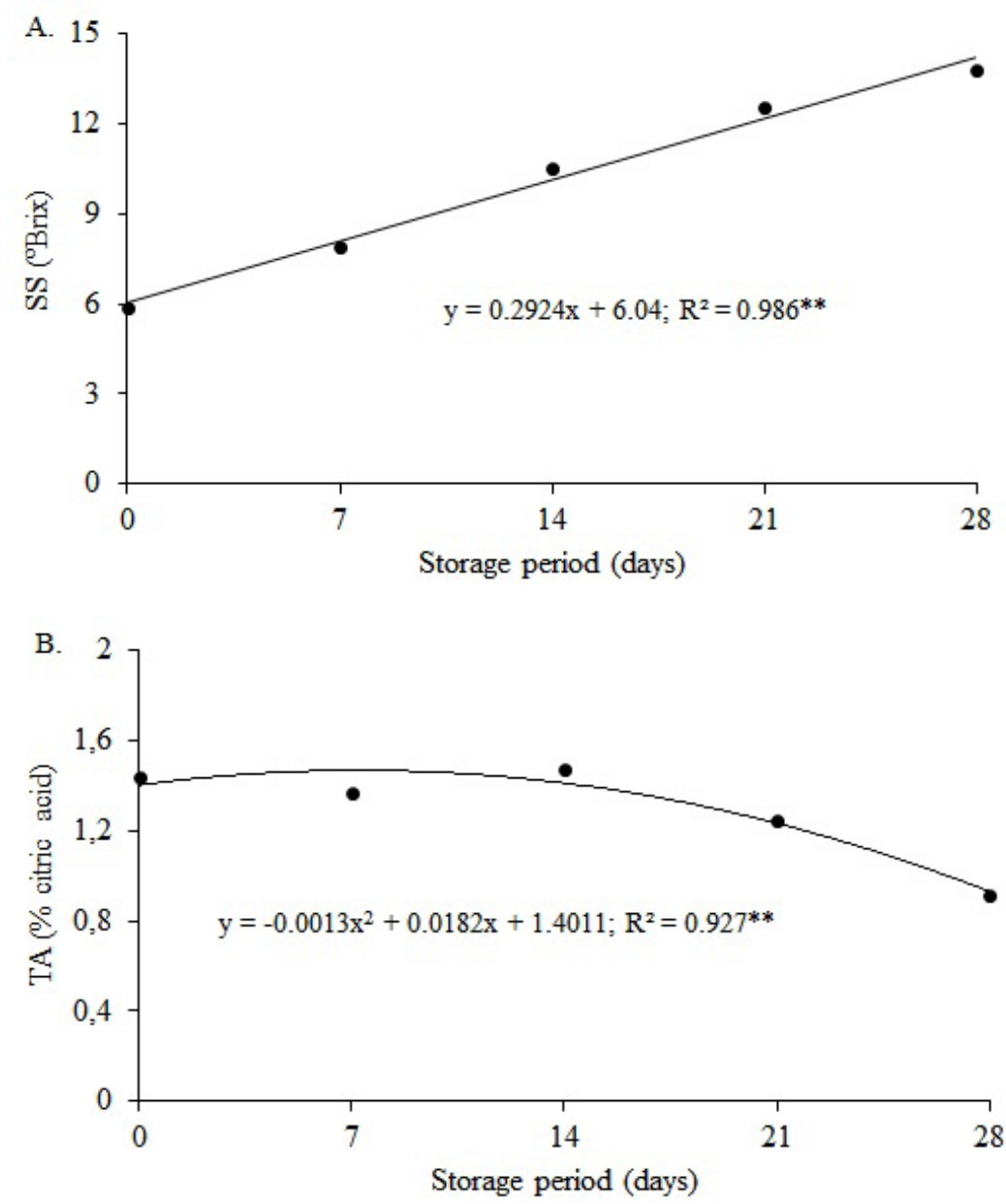

Figure 11. Soluble solids - SS (A) and titratable acidity - TA (B) of 'Palmer' mangoes stored for twenty-eight days under refrigeration. 
Regardless of vibration stress, the average increase in the soluble solids content of mangoes was $7.9^{\circ} \mathrm{Brix}$ at the end of the evaluations. Jung and Park (2012) observed that the soluble solids content of 'Fuji' apples increased significantly with storage time in all samples, with or without vibration stress, due to the conversion of starch into sugar. However, the increase was faster in apples subjected to vibration, which could be explained due to an increase in both temperature and enzymatic activity in the sugar transformation process, factors that possibly did not affect 'Palmer' mangoes with the same intensity.

Mean titratable acidity decreased from $1.44 \%$ at the beginning of storage to $0.91 \%$ at the end of the twenty-eight days of storage, being associated with decreased organic acids in the respiratory process and their conversion into sugars (FAASEMA et al., 2014), regardless of vibration. Serpa et al. (2014) also observed that the time factor was decisive in reducing acidity of 'Palmer' mangoes from 0.5 to $0.3 \%$ (citric acid) during storage.

\section{Conclusions}

At the end of the development of the vibration machine it was possible to satisfactorily simulate specific vibration frequencies, allowing comparison between laboratory experiments and real fruit transport processes.

'Palmer' mango quality was affected by impact stress during simulated transport, with accelerated weight loss, decreased pulp firmness, and peel browning, which reduce shelf life; in addition, the appearance of spots may influence the acceptance of the consumer market.

\section{Acknowledgment}

The authors thank the authors thank the Coordination for the Improvement of Higher Education Personnel (CAPES) for granting the Doctorate Scholarship and GrandValle Farm.

\section{References}

ALTENDORF, S. Major tropical fruits market review 2017, 2019. Disponível em: http://www.fao.org/fileadmin/ templates/est/COMM MARKETS MONITORING/ Tropical_Fruits/Documents/CA2895EN.pdf. 2019. Acesso em: Agosto 2019.

ALVES, R.E.; FILGUEIRAS, H.A.C.; MENEZES, J.B.; ASSIS, J.S.; LIMA, M.A.C.; AMORIM, T.B.F.; MARTINS, A.G. Colheita e pós-colheita. In: GENÚ, P.J.C.; PINTO, A.C.Q. (ed.). A cultura da mangueira. Brasília, DF: Embrapa Informações Tecnológica, 2002. p. $380-405$.
ASSIS, J. S. Cultivo da mangueira: colheita e póscolheita. Petrolina: Embrapa Semiárido, 2004.

COSTA, J.D.S.; ALMEIDA, F.A.C.; FIGUEIREDO NETO, A.; COSTA, M.S.; FERREIRA, E.A. Vida útil de mangas 'Tommy Atkins' armazenadas em embalagem XTend sob refrigeração e condição ambiente. Revista Espacios, Caracas, v.38, n.39, p.27, 2017.

EMBRAPA- Empresa Brasileira de Pesquisa Agropecuária. Manga: pós-colheita. Brasília, DF: Embrapa Comunicação para Transferência de Tecnologia, 2000. p.14.

FAASEMA, J.; ALAKALI, J.S.; ABU, J. Effects of storage temperature on 1-methylcycllopropene treated mango (Mangifera indica) fruit varieties. Journal of Food Processing and Preservation, Oxford, v.38, p.289-295, 2014.

IAL - Instituto Adolfo Lutz. Métodos físico-químicos para análise de alimentos. São Paulo, 2008. 1020p.

JUNG, H.M.; LEE, S.; LEE, W.H.; CHO, B.K.; LEE, S.H. Effect of vibration stress on quality of packaged grapes during transportation. Engineering in Agriculture, Environment and Food, Okayama, v.11, n.2, p.79-83, 2018.

JUNG, H.M; PARK, J.G. Effects of Vibration stress on the quality of packaged apples during simulated transport. Journal of Biosystems Engineering, Seoul, v.37, n.1, p.44-50, 2012.

MIGUEL, A.C.A.; DURIGAN, J.F.; BARBOSA, J.C.; MORGADO, C.M.A. Qualidade de mangas cv. Palmer após armazenamento sob baixas temperaturas. Revista Brasileira de Fruticultura, Jaboticabal, v.35, n.2, p.398408, 2013.

OLIVEIRA, A.N. Pectinas de casca de manga (Mangífera indica L.) cv. Ubá: otimização da extração, caracterização físico-química e avaliação das propriedades espessantes e gelificantes. 2013. Tese (Doutorado em Ciência e Tecnologia de Alimentos) - Universidade Federal de Viçosa, Viçosa, 2013.

PATERNOSTER, A.; VANLANDUIT, S.; SPRINGAEL, J.; BRAET, J. Vibration and shock analysis of specific events during truck and train transport of food products. Food Packaging and Shelf Life, Amsterdam, v.15, p.95104, 2018. 
PATHARE, P.B.; OPARA, U.L.; AL-SAID, F.A.J. Colour measurement and analysis in fresh and processed foods: a review. Food and Bioprocess Technology, New York, v.6, n.1, p.36-60, 2013.

SERPA, M.F.P.; CASTRICINI, A.; MITSOBUZI, G.P.; MARTINS, R.N.; BATISTA, M.F.; ALMEIDA, T.H. Conservação de manga com uso de fécula de mandioca preparada com extrato de cravo e canela. Revista Ceres, Viçosa, MG, v.61, n.6, p.975-982, 2014.

SHAHBAZI, F.; RAJABIPOUR, A.; MOHTASEBI, S.; RAFIE, S. Simulated in-transit vibration damage to watermelons. Journal of Agricultural Science and Technology, Tehran, v.12, n.1, p.23-34, 2010.

SILVA, F.A.S.; AZEVEDO, C.A.V. The Assistat Software Version 7.7 and its use in the analysis of experimental data. African Journal of Agricultural Research, Nsukka, v.11, p.3733-3740, 2016.

SILVA, S. Vibrações mecânicas. Foz do Iguaçu: Unioeste, 2009. 151p. Disponível em: http://www. joinville.ifsc.edu.br/ pauloboni/MECANISMOS/ DIN\%C3\%82MICA\%20DE\%20M\%C3\%81QUINAS/ Apostila \%20-\%20Samuel $\% 20$ da $\% 20$ SIlva $\% 20-\% 20$ MUITO\%20BOA\%20-\%20Did\%C3\%A1tica.pdf. Acesso em: Abril 2019.
SPRINGAEL, J.; PATERNOSTER, A.; BRAET, J. Reducing postharvest losses of apples: Optimal transport routing (while minimizing total costs). Computers and Electronics in Agriculture, Amsterdam, v.146, p.136144, 2018.

TABATABAEKOLOOR, R; HASHEMI, S.J; TAGHIZADE, G. Vibration damage to kiwifruits during road transportation. International Journal of Agriculture and Food Science Technology, Owerri, v.4, n.5, p.467- 474, 2013.

WASALA, W.M.C.B.; DHARMASENA, D.A.N.; DISSANAYAKE, T.M.R.; THILAKARATHNE, B.M.K.S. Vibration simulation testing of banana bulk transport packaging systems. Tropical Agricultural Research, Kandy, v.26, n.2, p.355-367, 2015.

WEI, X.; XIE, D.; MAO, L.; XU, C.; LUO, Z.; XIA, M.; ZHAO, X.; HAN, X.; LU, W. Excess water loss induced by simulated transport vibration in postharvest kiwifruit. Scientia Horticulturae, New York, v.250, p.113-120, 2019.

ZHOU, R.; WANG, X.; HU, Y.; ZHANG, G.; YANG, P.; HUANG, B. Reduction in Hami melon (Cucumis melo var. saccharinus) softening caused by transport vibration by using hot water and shellac coating. Postharvest Biology and Technology, Amsterdam, v.110, p.214-223, 2015. 